\title{
Strategi Adaptasi Nelayan Terhadap Dampak Perubahan Lingkungan (Studi Kasus : Pemanfaatan Teknologi Penangkapan Ikan Laut)

\author{
SAUT A.H. SAGALA ${ }^{1}$, TETI A. ARGO ${ }^{1}$, ASIRIN $^{1}$, PRADITYA ADHITAMA ${ }^{2,}$, DODON ${ }^{2}$. \\ ${ }^{1)}$ Sekolah Arsitektur, Perencanaan, dan Pengembangan Kebijakan, Institut Teknologi \\ Bandung \\ Jl. Ganesha No. 10, Bandung
} \\ 2) Resilience Development Initiative, \\ Jl. Imperial II no 52, Bandung
}

\begin{abstract}
ABSTRAK
Tulisan ini mengkaji adaptasi yang dilakukan oleh nelayan berupa pemanfaatan teknologi untuk bertahan dan meningkatkan produksi ikan tangkap dalam menghadapi tekanan dampak perubahan dan variabilitas iklim. Pendekatan kualitatif dipilih di dalam penelitian ini untuk menggali secara mendalam kepada pihak-pihak yang memahami permasalahan, diantaranya nelayan (pemilik kapal/juragan, anak buah kapal, nahkoda kapal, nelayan perahu kecil) yang memiliki minimal 10 tahun pengalaman, manajer koperasi nelayan Misaya Mina, serta Dinas Perikanan dan Kelautan Indramayu. Teknologi telah dimanfaatkan oleh nelayan perikanan tangkap (seperti kapal, alat tangkap, serta geoinformasi dan komunikasi) dalam beradaptasi terhadap dampak perubahan iklim. Sejauh ini, terdapat beberapa tantangan berupa keterbatasan kepemilikan finansial dan lemahnya akses finansial untuk terus meningkatkan kapasitas adaptasi menggunakan teknologi. Penelitian ini menemukan bahwa penyediaan modal saja tidak cukup untuk mendorong peningkatan pemanfaatan teknologi untuk adaptasi, tetapi penting juga adanya upaya-upaya menguatkan kapasitas masyarakat dalam mengakses modal tersebut seperti pendampingan penguatan kolektifitas kelompok nelayan dan pendampingan teknis (technical assistance) dalam pembuatan proposal sampai pemanfaatan modal.
\end{abstract}

Kata Kunci: Teknologi, Komunitas Nelayan, Adaptasi, variabilitas dan perubahan iklim 


\section{PENDAHULUAN}

Perubahan iklim telah dirasakan secara langsung pada sektor perikanan dan kelautan. Nelayan tangkap sangat rentan terhadap dampak perubahan dan variabilitas iklim karena mengandalkan laut sebagai sumber mata pencaharian dalam kehidupannya. Akan tetapi, iklim dan cuaca berperan dalam menentukan kemudahan nelayan untuk menjangkau sumber daya perikanan di laut. Lingkungan yang memburuk akibat perubahan iklim akan menimbulkan tekanan pada struktur sosial dan mata pencaharian masyarakat (Adger et al., 2002). Dampak variabilitas dan perubahan iklim seperti kejadian ekstrim (badai, gelombang tinggi), cuaca yang tidak menentu, dapat mengganggu hasil tangkapan ikan nelayan di laut. Variabilitas dan perubahan iklim seperti peningkatan frekuensi dan besarnya badai mengganggu operasional nelayan dalam hal keselamatan dan efisiensi (Badjeck, et al).

Sebagai contoh, dampak perubahan iklim telah berpengaruh terhadap penurunan hasil tangkapan nelayan di Tasmania, Australia (Australian Government, 2009), Rio de la Plata, Argentina (Nagy et al., 2006) serta Indramayu, Indonesia (UNDP, 2007; Sani, 2012).

Perikanan tangkap memiliki peran penting dalam penyediaan bahan pangan dan pendorong ekonomi suatu wilayah khususnya pada daerah pesisir. Perikanan tangkap juga dapat memenuhi kebutuhan bahan pangan ikan dalam rangka menjaga ketahanan pangan suatu wilayah (Kent, 1998; Pauly, et al, 2013). Selain itu, perikanan tangkap memiliki efek pengganda yang dapat menggerakkan usaha-usaha lainnya pada wilayah tersebut. Pada kasus studi Indramayu, perikanan tangkap menggerakkan usaha lain seperti pengolahan ikan, usaha es, usaha pembuatan/perbaikan kapal dan perlengkapan kapal, yang mampu menyerap tenaga kerja (Omat, 2004). Pada tahun 2009, jumlah produksi ikan tangkap
90.801,4 ton dengan nilai produksi ikan tangkap yang didaratkan di Indramayu yang terdata sebesar Rp 1,2 Triliun (BPS, 2010). Jumlah tersebut belum termasuk produksi ikan yang tidak tercatat yang langsung dijual ke pengepul. Produksi ikan tersebut selain memenuhi kebutuhan ikan di Indramayu juga memenuhi kebutuhan ikan di wilayah lain seperti metropolitan Bandung terutama metropolitan Jakarta yang dekat dengan wilayah Indramayu karena adanya akses jalur Pantura.

Masyarakat nelayan yang terkena dampak perubahan iklim melakukan adaptasi sebagai respon dari tekanan akibat perubahan-perubahan kondisi yang dirasakan. Untuk kasus Indramayu misalnya, masyarakat nelayan melakukan adaptasi dalam hal mata pencaharian. Adaptasi tersebut dilakukan dengan melakukan diversifikasikan risiko mata pencaharian. Salah satu contohnya adalah dengan adanya anggota keluarga yang menjadi tenaga kerja di luar negeri untuk menghasilkan dana remitan sehingga dapat digunakan oleh anggota keluarga yang lain dari tempat asalnya (Sagala et al., 2012). Selain adaptasi mata pencaharian, nelayan dapat beradaptasi dengan memanfaatkan teknologi. Teknologi yang dimanfaatkan untuk beradaptasi tersebut dapat berasal dari hasil pengembangan yang dilakukan oleh masyarakat nelayan sendiri maupun teknologi yang bersumber dari pihak lain. Berbagai teknologi yang dapat diakses nelayan akan memberi kesempatan baru untuk mengubah kegiatan nelayan agar mampu menghadapi tantangan perubahan iklim.

Kajian proses adaptasi nelayan yang berbasis teknologi perlu dilakukan. Sejauh tinjauan terhadap pustaka berupa artikel jurnal yang telah dilakukan, penelitian mengenai penggunaan teknologi oleh masyarakat nelayan dalam merespon dampak perubahan iklim masih sedikit. Klein et al. (2001) melakukan penelitian mengenai pilihan-pilihan teknologi untuk adaptasi di kawasan pesisir sekitar 20an tahun yang lalu. Penelitian tentang adaptasi 
di kawasan pesisir yang dilakukan Klein et al. (2001) tersebut masih bersifat umum dan belum secara spesifik mengkaji pilihan-pilihan teknologi untuk adaptasi masyarakat nelayan dalam hal penggunaan teknologi untuk mendukung mata pencaharian nelayan ikan tangkap (lihat Klein, 2001). Selain itu, kajian ini diperlukan dalam rangka mengeksplorasi permasalahan pemanfaatan teknologi pada kasus nelayan di Indramayu untuk kemudian mengusulkan alternatif pemecahan masalah tersebut.

Penelitian ini bertujuan untuk mengeksplorasi fenomena adaptasi nelayan, lalu melihat bagaimana dukungan pemerintah dalam pemanfaatan teknologi untuk adaptasi masyarakat nelayan, serta ingin melihat bagaimana tantangan pemanfaatan teknologi untuk bertahan dan meningkatkan produksi ikan tangkap dalam menghadapi tekanan dampak perubahan dan variabilitas iklim. Penelitian ini menjawab pertanyaan penelitian "bagaimana pemanfaatan teknologi oleh nelayan untuk adaptasi terhadap dampak variabilitas dan perubahan iklim?" Penelitian ini lebih spesifik akan menjawab beberapa subpertanyaan penelitian : (1) Apa teknologi yang dimanfaatkan oleh nelayan? (2) Apa kebijakan pemerintah dalam mendukung peningkatan pemanfaatan teknologi? (3) Apa saja kendala dan tantangan masyarakat nelayan dalam pemanfaatan teknologi? Pembahasan akan dimulai dengan mengulas konsep teknologi dan adaptasi terhadap variabilitas dan perubahan iklim. Konteks lokasi studi kasus, metode pengumpulan data dan analisis diuraikan pada bagian Metodologi. Bagian selanjutnya mengulas data dan hasil analisis yang membahas fenomena adaptasi nelayan, dukungan pemerintah dan tantangan pemanfaatan teknologi untuk adaptasi dampak variabilitas dan perubahan iklim. Bagian akhir akan menyajikan sintesa dan kesimpulan dari penelitian yang dilakukan.

\section{METODE}

Bagian ini menjelaskan mengenai pendekatan penelitian, metode pengumpulan data, metode analisis dan lokasi studi.

\subsection{Pendekatan, Metode Pengumpulan Data dan Metode Analisis}

Penelitian ini menggunakan pendekatan kualitatif dengan melalui wawancara pada pihak-pihak yang memahami persoalan seperti nelayan (pemilik kapal/juragan, anak buah kapal, nahkoda kapal, nelayan perahu kecil) yang memiliki minimal 10 tahun pengalaman, manajer koperasi nelayan Misaya Mina, dan Dinas Perikanan dan Kelautan Indramayu. Analisis data kualitatif dilakukan dengan open coding, axial coding, timeline analysis dan triangulasi data dari berbagai sumber kemudian dilakukan sintesis dan penarikan kesimpulan.

\subsection{Lokasi Studi}

Penelitian ini mengambil lokasi penelitian di Kabupaten Indramayu. Lokasi studi ini memiliki akses yang sangat tinggi dengan jalur Pantura (Pantai Utara) Indramayu yang merupakan jalur transportasi nasional. Indramayu dijadikan lokasi studi karena merupakan wilayah yang memiliki kompleksitas aktor-aktor dan kompleksitas interaksi antar aktor pada komunitas nelayan. Aktor-aktor yang ada di lokasi studi antara lain nelayan-nelayan perahu kecil, awak kapal (nelayan pekerja), pemilik kapal besar, pihak pengelola tempat pendaratan ikan (TPI), pihak koperasi nelayan (Koperasi Misaya Mina) dan pemerintah.

\section{Hasil : Dampak Perubahan Iklim terhadap lingkungan}

Bagian ini membahas temuan-temuan dari hasil pegumpulan data dan analisis. Temuan tersebut meliputi dampak perubahan iklim terhadap nelayan, fenomena adaptasi dengan memanfaatan teknologi produksi ikan tangkap, gambaran 
dukungan kebijakan pemerintah, dan sintesis tantangan pemanfaatan teknologi untuk adaptasi terhadap dampak variabilitas dan perubahan iklim di Indramayu.

Tingginya gelombang pasang yang terjadi akibat perubahan iklim diakui nelayan berdampak pada hasil tangkapan ikan. Jika terjadi gelombang pasang, nelayan tidak dapat terlalu jauh melaut bahkan bisa sampai tidak melaut.

Perubahan iklim yang terjadi selain mempengaruhi curah hujan, juga mempengaruhi pola angin. Curah hujan yang tidak menentu berpengaruh terhadap perubahan pola datangnya angin sehingga berdampak pada perubahan tekanan di perairan laut Indonesia yang mengakibatkan tingginya gelombang. Tingginya gelombang juga dikarenakan volume air laut yang semakin meningkat.

Dinas Perikanan dan Kelautan Indramayu menyatakan hal yang sama sebagai dampak dari perubahan iklim:

"Perubahan iklim mulai dirasakan pada tahun 2004 dimana gelombang laut menjadi semakin tinggi dan bencana rob. Bencana rob yang terjadi menyerang daerah pertambakan yang berada di daerah pesisir seperti yang terjadi di wilayah barat kabupaten indramayu, contohnya kecamatan kandanghaur. Selain itu, terdapat perubahan iklim di perairan Indramayu yang mengakibatkan terjadinya perubahan lokasi fishing ground menjauhi bibir pantai. Hal ini juga diakibatkan karena adanya pencemaran di daerah pesisir."

Cuaca yang tidak menentu dan sulit diprediksi dalam 4-5 tahun terakhir ini diakui para nelayan sehingga menyebabkan mereka tidak melaut dalam beberapa hari. Lokasi penangkapan ikan yang biasanya di daerah pesisir, berpindah lebih jauh ke laut lepas.

(Nelayan 5) "Musim barat (musim hujan) banyak menyebabkan gelombang besar,di tahun (2010), pernah tidak berangkat selama 5 hari ke pantai karena gelombang tinggi. Sekarang pun kalau pergi melaut harus sejauh 8 mil (10 km dari bibir pantai) baru mendapatkan ikan."

Peningkatan suhu yang terjadi secara global di seluruh dunia ini juga terjadi di Indramayu. Perubahan iklim tersebut berdampak pada kenaikan permukaan air laut, peningkatan glAsial, permafrost, dan es yang mencair di Antartika; peningkatan curah hujan di beberapa wilayah; lebih banyak kekeringan di daerah tropis dan subtropis; serta bahaya badai yang lebih intens (Oliver-Smith et al., 2009). Bencana yang terjadi di Kabupaten Indramayu akan dibahas secara lebih mendalam pada sub bab berikutnya.

\subsection{Dampak Perubahan Lingkungan terhadap Masyarakat Nelayan di Indramayu}

Secara umum dilihat dari sisi produksinya, produksi ikan tangkap Indramayu secara makro mengalami peningkatan (lihat Gambar 1). Pada tahun 1995 produksi ikan tangkap sebesar 60.207 ton kemudian pada tahun 2009 meningkat menjadi 90.801 ton. Peningkatan tersebut dapat sejalan dengan meningkatnya kapasitas sarana dan prasarana penangkapan ikan laut seperti kapasitas kapal dan alat tangkap (lihat Gambar 2 dan Gambar 3).

Namun, dampak perubahan dan variabilitas iklim secara nyata dirasakan oleh nelayan Indramayu mengganggu usaha mereka dalam penangkapan ikan laut. Cuaca ekstrim membuat badai gelombang yang mengganggu usaha penangkapan ikan di laut dan dapat membahayakan keselamatan nelayan. Angin kencang disertai gelombang tinggi sekitar tiga hingga empat meter terjadi di perairan Indramayu selama desember 2011 sampai februari 2012 yang menyebabkan nelayan tidak bisa melaut (bisnis-jabar, 2012). Sebagai contoh lainnya, dikabarkan 3 orang meninggal akibat badai di perairan Indramayu (Kompas, 2009). Di Indramayu, variabilitas iklim berupa cuaca yang tidak menentu dan tidak dapat diprediksi 
mengganggu keputusan nelayan untuk melaut. Hal yang terjadi adalah laut tibatiba menjadi keruh karena cuaca yang yang tiba-tiba berganti sehingga menyulitkan upaya penangkapan ikan di laut. Dampak perubahan iklim berupa peningkatan intensitas dan frekuensi badai mempengaruhi operasional nelayan dalam hal mengganggu keselamatan dan efisiensi operasional nelayan di laut (Badjeck, et al., 2010).

"Sekitar 20 tahun lalu, cuaca masih bisa ditebak. Sekarang cuaca tidak bisa diprediksi, harusnya bulan ini (bulan Juni) angin timur. Kemarin angin laut (angin utara) enak untuk melaut, kalau timur otomatis nganggur, kalo timur airnya butek (keruh). Harusnya angin timur bulan tujuh ini, tapi masih berganti-ganti, kadang timur, kadang laut, kadang barat. Kondisi cuaca yang sulit ditebak dan berganti-ganti tersebut menyulitkan keputusan melaut dan mengganggu usaha saya menangkap ikan di laut" (Hasil wawancara nelayan Indramayu, 2013).

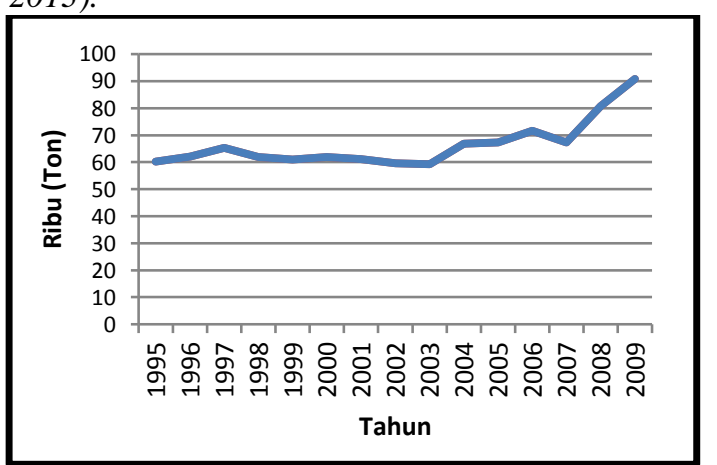

Gambar 1 Tren Produksi Ikan Tangkap di Indramayu

Sumber: BPS, 1995-2009

\section{Pembahasan}

\subsection{Pemanfaatan Teknologi untuk Produksi Ikan Tangkap dalam menghadapi Perubahan Iklim oleh Masyarakat Nelayan}

Dalam menghadapi dampak variabilitas dan perubahan iklim, nelayan melakukan adaptasi dengan memanfaatkan teknologi perikanan tangkap. Teknologi utama dalam hal produksi ikan tangkap antara lain armada kapal, teknologi pendingin, alat tangkap, dan teknologi geoinformasi dan komunikasi.

\section{a. Teknologi Kapal}

Salah satu indikasi adanya fenomena nelayan beradaptasi dengan memanfaatkan teknologi adalah meningkatnya penggunaan kapal bermotor (lihat Gambar 2). Pada tahun 1995 nelayan di Indramayu menggunakan kapal motor tempel sebanyak 3.999 unit. Jumlah tersebut meningkat pada tahun 2009 menjadi 5.620. Dari jenis Kapal Motor, pada tahun 1995 sebanyak 136 unit saja di Indramayu. Namun, pada tahun 2009, jumlah tersebut meningkat menjadi 408 unit.

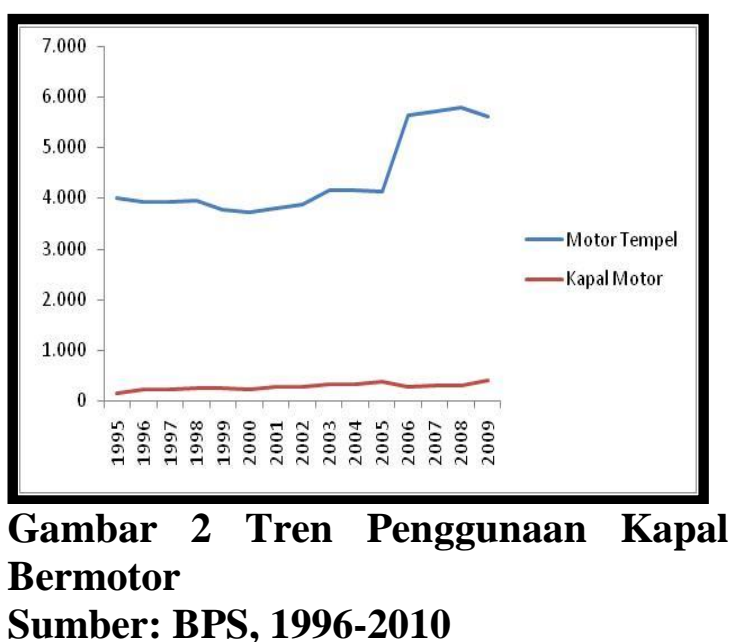

Cuaca yang tiba-tiba berubah memberikan tekanan pada nelayan yang kemudian nelayan meresponnya dengan salah satunya dengan menggunakan armada Kapal Motor yang memiliki daya jelajah yang lebih tinggi. Fakta tersebut dapat dilihat dari pernyataan nelayan sebagai berikut:

"Cuaca mempengaruhi paling utama usaha saya sebagai nelayan. Bapak saya nelayan dari memakai perahu dayung belum ada mesin, masih menggunakan alat tradisional. Kalau Kapal Motor besar dengan alat tangkap Gillnet itu lebih enak, jangkauannya luas. Jadi jika disini (perairan Indramayu) angin barat yang merupakan cuaca yang tidak mendukung untuk menangkap ikan tetapi di luar sana seperti di perairan Kalimantan tidak angin barat, Kapal Motor besar dengan alat tangkap Gillnet dapat menjangkau sehingga tetap dapat beroperasi menangkap ikan pada kondisi cuaca tersebut" (Wawancara dengan Nelayan, 2013).

Armada penangkapan ikan dengan Kapal Motor menjadikan nelayan mampu 
menjangkau jarak wilayah tangkapan yang lebih jauh sehingga jangkauan wilayah lebih luas dalam merespon tekanan perubahan iklim berupa cuaca yang tidak menentu. Jangkauan yang lebih luas tersebut membuat nelayan dapat memiliki banyak pilihan titik lokasi menggelar jaring untuk menangkap ikan. Dengan semakin banyaknya pilihan titik lokasi tersebut membuat nelayan mampu menghindar dan berpindah dari suatu titik lokasi wilayah laut yang tiba-tiba terjadi perubahan cuaca ke titik lain yang cenderung cuacanya lebih baik. Perubahan cuaca tersebut biasanya ditandai dengan perubahan arah tiupan angin. Dengan begitu, nelayan di wilayah laut lepas dapat menyelamatkan diri dari cuaca buruk seperti badai yang tiba-tiba datang. Selain itu, nelayan juga dapat berpindah ke titik lokasi lain yang memungkinkan nelayan menggelar jaring tanpa gangguan cuaca buruk.

\section{b. Teknologi Alat Tangkap}

Selain dari sisi armada tangkap, indikasi fenomena nelayan memanfaatkan perkembangan teknologi untuk beradaptasi menghadapi tekanan perubahan iklim adalah perubahan penggunaan alat tangkap. Secara makro, perubahan alat tangkap tersebut dapat dilihat dari data statistik penggunaan alat tangkap nelayan di Indramayu (lihat Gambar 3). Dari data tersebut diduga terdapat perubahan penggunaan alat tangkap ikan laut yang digunakan nelayan dengan indikasi adanya penurunan penggunaan alat tangkap tertentu (seperti pancing, sero, klitik), di sisi lain terjadi peningkatan penggunaan alat tangkap lainnya (seperti gillnet, pursein, payang dan pukat pantai).

Secara umum, terdapat penurunan jumlah penggunaan alat tangkap Jaring Klitik secara drastis namun disisi lain penggunaan alat tangkap seperti Gillnet meningkat secara drastis. Pada tahun 1995, jumlah penggunaan alat tangkap Jaring Klitik sebanyak 3.274 unit. Berdasarkan hasil wawancara didapatkan bahwa perubahan alat tangkap tersebut terjadi karena meningkatnya kemampuan serta pemahaman para nelayan akan alat tertentu sehingga alat tangkap yang bersifat kuno cenderung ditinggalkan. Selain itu meningkatnya alat tangkap pursein, gillnet, dan jaring cumi juga terjadi karena hasil tangkapan alat tangkap tersebut menghasilkan ikan tangkap yang lebih banyak. Untuk alat tangkap pursein sendiri biasanya menghabiskan modal sekitar 60 juta rupiah dan ikan yang biasa ditangkap diantaranya adalah ikan bandeng, tongkol, dsb.

Jumlah tersebut menurun drastis menjadi 334 unit saja pada tahun 2009. Di sisi lain, penggunaan alat tangkap jaring Gillnet meningkat drastis dari sebanyak 1.591unit pada tahun 1995 menjadi sebanyak 2.976 unit pada tahun 2009. Selain itu, salah satu alat tangkap yang meningkat drastis adalah alat tangkap pukat pantai. Alat tangkap ini dgunakan dengan menebar jaring di perairan laut dekat tepi pantai yang tidak memiliki risiko besar terhadap variabilitas iklim dan cuaca ekstrim yang dapat tiba-tiba datang. Peningkatan penggunaan alat tangkap pukat pantai tersebut dapat menjadi indikasi adanya fenomena masyarakat nelayan untuk menjaring ikan di tepi pantai untuk menghindari risiko iklim (variabilitas cuaca dan cuaca ekstrim) yang biasa terjadi di tengah laut 


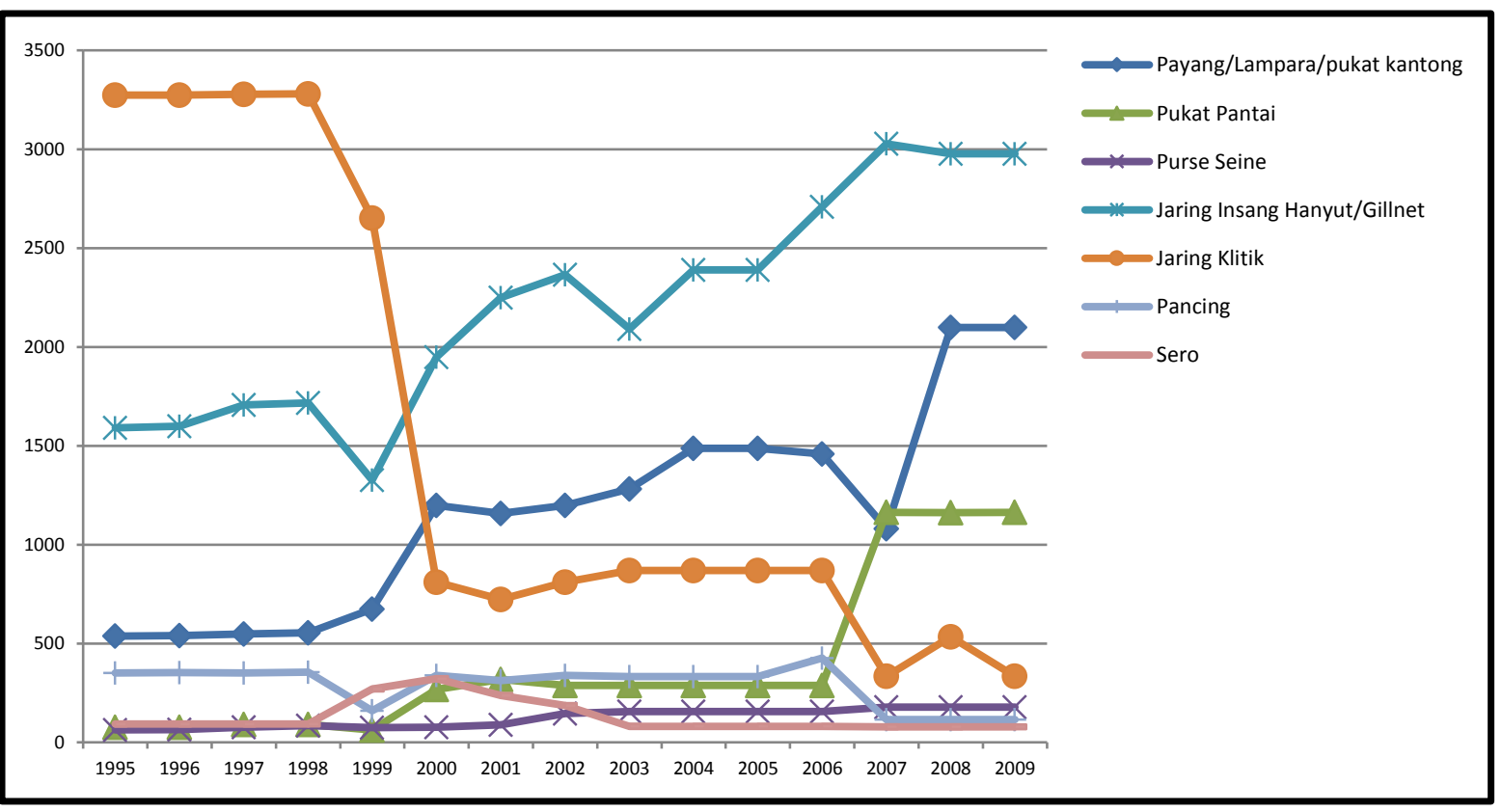

Gambar 3 Tren Penggunaan Alat Tangkap Nelayan di Indramayu Sumber: BPS, 1996-2010

Tabel 1 Perbedaan Karakteristik Penggunaan Alat Tangkap Gillnet dan Pursein di Indramayu

\begin{tabular}{|c|c|c|c|}
\hline No. & $\begin{array}{c}\text { Aspek } \\
\text { Pembeda }\end{array}$ & Pursein & Gillnet \\
\hline 1. & $\begin{array}{c}\text { Jumlah } \\
\text { ABK }\end{array}$ & $20-30$ orang & $10-15$ orang \\
\hline 2. & $\begin{array}{c}\text { Lama } \\
\text { melaut }\end{array}$ & $\begin{array}{c}2 \text { minggu-1 } \\
\text { bulan }\end{array}$ & $1-2$ bulan \\
\hline 3. & $\begin{array}{c}\text { Jangkauan } \\
\text { jarak } \\
\text { melaut } \\
\text { (perairan } \\
\text { Indramayu, } \\
\text { kepulauan } \\
\text { seribu) }\end{array}$ & $\begin{array}{c}>100 \text { mil } \\
\text { (perairan } \\
\text { kalimantan, } \\
\text { natuna) }\end{array}$ \\
\hline pendingin & $\begin{array}{c}\text { Pada } \\
\text { umumnya } \\
\text { mengunakan } \\
\text { Es }\end{array}$ & freezer \\
\hline
\end{tabular}

Sumber: diolah dari hasil wawancara nelayan, 2013

Secara mikro, temuan fakta di lapangan menunjukkan adanya perubahan penggunaan alat tangkap. Sebagai contoh, nelayan dengan alat tangkap pursein, banyak beralih menjadi nelayan dengan alat tangkap gillnet. Nelayan Indramayu yang mendapatkan tekanan perubahan iklim terutama dari aspek cuaca yang tidak menentu selain membutuhkan kapal motor besar juga membutuhkan alat tangkap yang lebih efisien. Kondisi tersebut dimaksudkan agar mampu mengimbangi kebutuhan jarak jelajah laut yang lebih jauh dan luas dalam mencapai titik lokasi yang tidak terganggu cuaca buruk. Menurut pengalaman nelayan di Indramayu, lat tangkap Gillnet dianggap lebih efisien digunakan untuk menjangkau laut yang lebih jauh (lihat tabel 1).

\section{c. Teknologi Sistem GeoInformasi dan Komunikasi}

Selain penggunaan kapal motor yang semakin meningkat dan perubahan jenis alat tangkap, indikasi lain nelayan Indramayu melakukan adaptasi dengan memanfaatkan teknologi dalam merespon dampak perubahan iklim adalah dengan memanfaatan teknologi informasi dan komunikasi seperti GPS, fishfinder, informasi titik koordinat lokasi daerah penangkapan ikan, radio, telefon seluler, dan running text. Dalam hal pemanfaatan teknologi informasi nelayan di Indramayu sudah lama mengenal dan menggunakan GPS sebagai pengganti kompas dan petunjuk arah tradisional (tanda-tanda dari alam) dalam menentukan arah dan lokasi. Perkembangan terkini, Pemerintah Indramayu sudah mengembangkan teknologi informasi daerah penangkapan ikan dan iklim (IDPI). IDPI memberikan informasi koordinat lokasi penangkapan ikan yang potensial banyak ikan dan 
kecepatan angin pada titik-titik lokasi tertentu. Pengembangan informasi tersebut memanfaatkan data dari Balai Penelitian dan Observasi Laut (BPOL) dan LAPAN. Adapun fishfinder untuk memastikan di suatu lokasi memang terdapat banyak ikan. Sedangkan dalam hal teknologi komunikasi, nelayan Indramayu sudah lama menggunakan radio komunikasi. Namun, setelah berkembangnya teknologi telefon seluler dan running text nelayan Indramayu juga memanfaatkan teknologi tersebut dalam berkomunikasi terutama dalam mendapatkan dan menyampaikan informasi cuaca dan titik lokasi penangkapan ikan. teman nelayan atau dari juragan kapal yang ada di darat.

"Saya hanya nelayan kapal dengan alat tangkap Pursein, saya sekitar 10 hari saja melaut. Yang pertama ikut penyuluhan di Diskanla tentang IDPI itu saya. Sejak ikut penyuluhan, saya tidak pernah menggunakan koordinat dari IDPI ini, kapal dengan alat tangkap Gillnet yang menggunakannya. Informasinya berguna untuk nelayan Gillnet dengan kapasitas kapal 30 GT atau lebih" (wawancara nelayan, 2013)

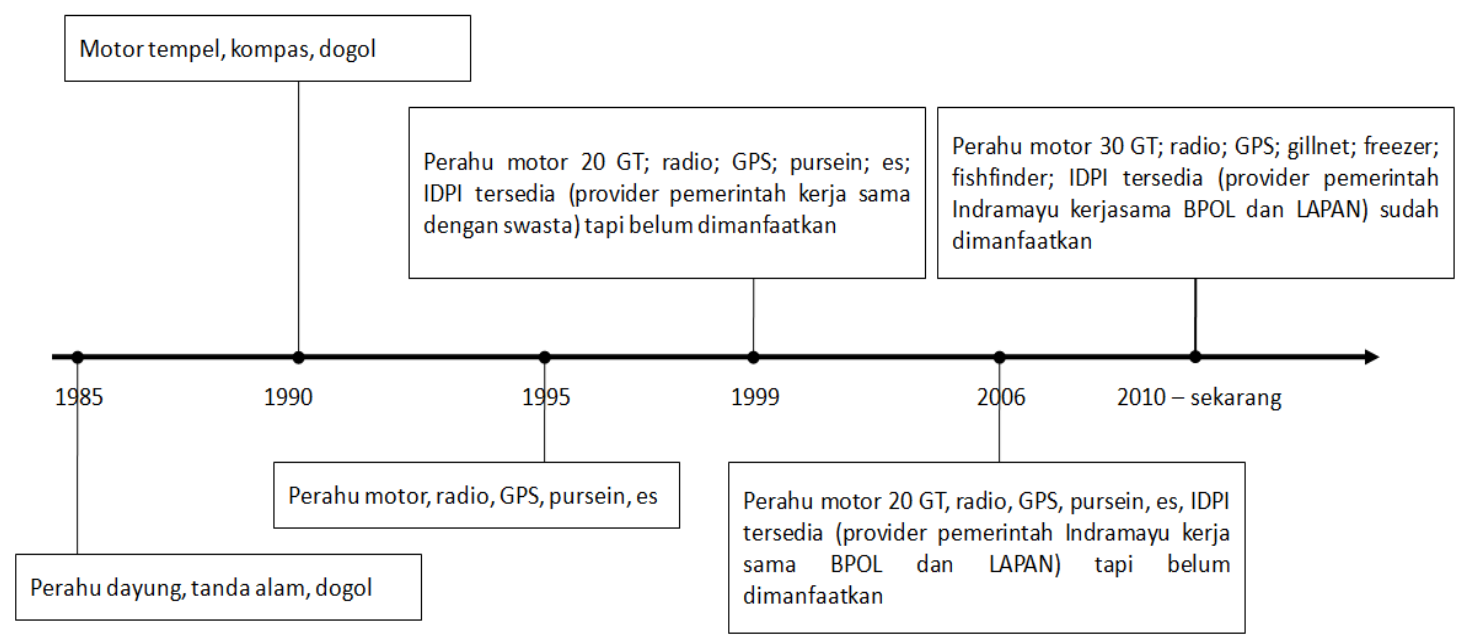

Gambar 4 Timeline Analysis Pemanfaatan Teknologi Produksi Ikan Tangkap Oleh Salah Satu Nelayan di Desa Eretan Wetan, Indramayu

Terkait respon terhadap perubahan iklim, nelayan Indramayu dengan kapal motor besar dan alat tangkap Gillnet saja yang memanfaatkan IDPI untuk mencapai titik lokasi yang banyak ikan dan kondisi angin di titik tersebut untuk merespon kondisi cuaca yang tidak menentu. Keterbatasan IDPI dalam memberikan informasi di lokasi yang jauh dari jangkauan membuat nelayan kecil tidak mampu memanfaatkan teknologi tersebut. Nelayan kecil hanya menggunakan teknologi lama berupa radio untuk mengakses informasi cuaca dan lokasi penangkapan ikan. Informasi yang didapatkan juga bukan dari IDPI karena informasi IDPI di luar jangkauan nelayan tersebut melainkan informasi dari sesama
Berdasarkan temuan tersebut, didapatkan keterbatasan dari pemanfaatan teknologi IDPI. Teknologi IDPI hanya dimanfaatkan nelayan kapal besar sementara masih banyak nelayan kapal kecil kecil (kurang dari 30 GT) yang belum memanfaatkan teknologi tersebut. IDPI tersebut hanya menyediakan informasi lokasi tertentu yang bukan merupakan jangkauan nelayan kecil. Dengan kata lain, program ini hanya berguna jika kapal besar dengan alat tangkap gillnet atau jaring cumi yang memiliki daya jelajah yang luas dan jauh.

Terdapat fenomena adaptasi teknologi untuk menghadapi tekanan dampak variabilitas dan perubahan iklim. Sebagai contoh, di Desa Eretan Wetan, sejak tahun 
2010, terdapat 3 nelayan yang berubah penggunaan teknologinya dari teknologi sederhana sampai menjadi menggunakan teknologi kapal besar $30 \mathrm{GT}$, alat tangkap Gillnet, GPS, freezer, fishfinder, dan IDPI yang disampaikan melalui SMS (short message service) dan running text. Fenomena adaptasi oleh nelayan dengan memanfaatkan teknologi untuk produksi ikan tangkap dapat diidentifikasi dari pengalaman salah satu nelayan di Desa Eretan Wetan melalui timeline analysis pada Gambar 4.

\subsection{Program Pemerintah Mendukung Pemanfaatan Teknologi Untuk Adaptasi Perubahan Iklim}

Pemerintah sebagai salah satu aktor yang berperan dalam adaptasi nelayan terhadap perubahan iklim melakukan beberapa intervensi untuk mendukung adaptasi perubahan iklim. Intervensi yang dilakukan diantaranya adalah sebagai berikut

$\begin{array}{llr}\text { a. Program Peningkatan } & \text { Armada } \\ \text { Penangkapan Ikan } & \text { dan } \\ \text { Perlengkapannya } & \text { (Program } \\ \text { “Pengkapalan") } & \\ \text { Untuk mendukung nelayan } & \\ \end{array}$ meningkatkan kapasitas kemampuan produksi ikan tangkap dengan peningkatan teknologi, pemerintah membuat program "pengkapalan". Program tersebut berupa pemberian kapal dari pemerintah kepada nelayan di Indramayu. Pada tahun 2012, Kementrian Kelautan dan Perikanan memberikan bantuan 3 (tiga) unit kapal di atas 30 GT senilai Rp. 4.500.000.000, dan paket sarana perikanan tangkap program peningkatan kesejahteraan nelayan senilai Rp. $\quad 339.000 .000$ kepada nelayan Indramayu (Humasindramayu.com, 2012). Pada Tahun 2012 kelompok nelayan Indramayu mendapatkan bantuan kapal dari KKP RI (Kementerian Kelautan dan Perikanan) Republik Indonesia dengan ukuran 30 GT, yaitu Kapal Inka Mina 357, Kapal Inka Mina 358, dan Kapal Inka Mina 359. Penyaluran bantuan bertempat di wilayah Eretan Wetan Kecamatan Kandanghaur, di wilayah Kel. Paoman Kec. Indramayu, serta kelompok nelayan yang ada di wilayah Limbangan Kec.Juntinyuat (Dinas Perikanan dan Kelautan Indramayu, 2012).

Muatan kapal 30 GT jauh lebih besar dibandingkan dengan kapal berbobot di bawah 10 GT. Kapal 30 GT bisa memuat sekitar 20 - 30 ton ikan (Dinas Perikanan dan Kelautan Jabar, 2011; bisnisjabar.com, 2011). Dengan meningkatnya muatan maka daya angkut kapal juga meningkat sehingga akan bsia memuat lebih banyak ikan tangkapan. Selain itu dengan kapal yang lebih besar berlayar menjangkau daerah lautan yang lebih jauh, sehingga tidak hanya mengarungi laut Jabar Utara,

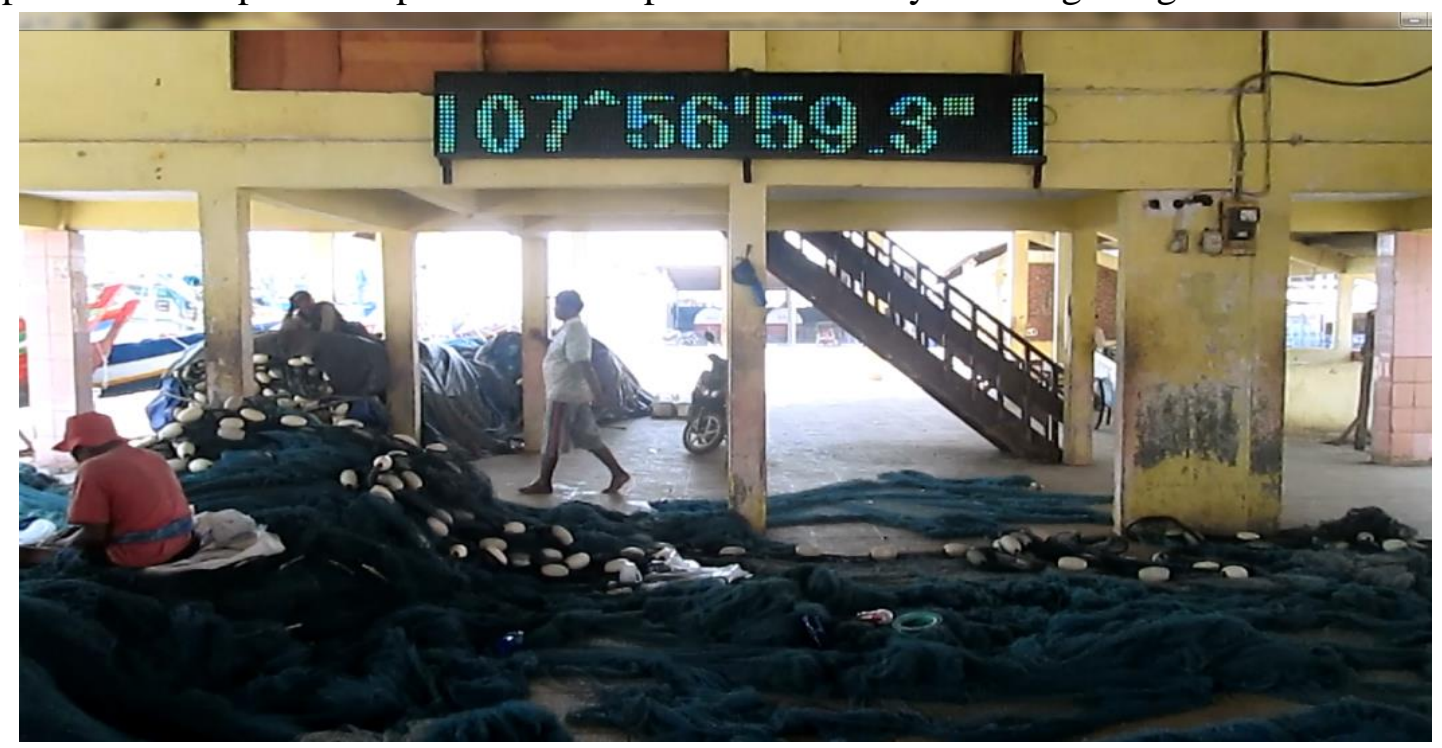

Gambar 5 Media IDPI dengan Running Text di TPI Desa Eretan Wetan, Indramayu Sumber: Observasi, 2013 
melainkan sampai Kalimantan dan Sumatera. Yang diharapkan adalah dengan semakin luasnya daerah mobilitas dan kapasitas kapal nelayan makan akan mendapatkan tangkapan ikan yang lebih banyak.

"Pemerintah memberikan bantuan kapal. Bantuan kapal tersebut untuk meningkatkan produksi tangkapan ikan. Bantuan kapal tersebut merupakan stimulan untuk kemudian perlengkapannya dilengkapi oleh kelompok nelayan" (wawancara dengan Kasubbid Pengembangan Teknologi Dinas Perikanan dan Keluatan Indramayu, 2013).

\section{b. Program Penyediaan Informasi Daerah Penangkapan dan Informasi Iklim}

Dalam hal kebijakan mendorong penggunaan teknologi untuk mendukung penangkapan ikan, pemerintah Indramayu memberikan program penyediaan informasi daerah penangkapan ikan dan informasi iklim (IDPI).Penyampaian Informasi Daerah Penangkapan Ikan (IDPI) di Indramayu diawali Tahun 1999 sumber informasi dari pihak swasta yang berorientasi profit yaitu Sky Fish. Sejak tahun 2006 sampai sekarang sumber data informasi daerah penangkapan ikan berasal dari Balai Penelitian dan Observasi Laut (BPOL) - Kementrian Kelautan dan Perikanan dan Lembaga Penerbangan dan Antariksa Nasional (LAPAN). Data di download melalui internet diolah berupa penyajian data koordinat (Derajat, Menit, dan Detik) disertai informasi kecepatan angin dan tinggi gelombang, setelah itu dipilih titik-titikkKoordinat yang sesuai dengan daya jelajah perahu nelayan Indramayu dilakukan 3 kali dalam seminggu. Penyebaran Informasi IDPI disebarluaskan melalui UPTD Perikanan dan Kelautan, KPL/KUD MINA di Indramayu, Para Nelayan dan Juragan yang sampai dengan tahun 2012 berjumlah 219 orang. Bantuan alat bantu penginformasian radio (bantuan Pemkab 9 Unit untuk di TPI), SMS CENTRE melalui nomor 081395503330, dan papan visual/running text di Kantor Dinas Perikanan dan Kelautan, di TPI
Karangsong dan Eretan Wetan. Penyampaian informasi mengenai iklim laut, maupun cuaca sangat membantu dalam mendukung peningkatan efektifitas, produktivitas penangkapan (Dinas Perikanan dan Kelautan, 2012).

\subsection{Tantangan Pemanfaatan Teknologi untuk Adaptasi Nelayan terhadap Perubahan Iklim}

Pemanfatan teknologi oleh masyarakat nelayan dalam beradaptasi terhadap dampak perubahan iklim dan variabilitas iklim merupakan suatu keharusan untuk dapat menjaga kelangsungan mata pencaharian dan produksi ikan tangkap. Hal itu teridentifikasi dari adanya kecenderungan peningkatan pemanfataan teknologi oleh masyarakat nelayan dalam aktivitas produksi kan tangkap. Namun, masyarakat nelayan menghadapi tantangan dalam meningkatkan pemanfaatan teknologi. Terdapat dua hal yang menjadi tantangan antara lain keterbatasan kepemilikan sumber daya finansial dan lemahnya akses terhadap sumber daya finansial.

\section{a. Keterbatasan Kepemilikan Sumber Daya Finansial}

Adanya tekanan dari perubahan iklim terhadap nelayan Indramayu seperti berupa cuaca yang tidak menentu mensyaratkan perlunya kapasitas kemampuan produksi ikan tangkap harus semakin besar untuk menjangkau wilayah yang lebih luas dan jarak yang lebih jauh dalam menghindari cuaca buruk yang tiba-tiba datang di suatu lokasi tertentu. Kapasitas kemampuan produksi nelayan Indramayu tersebut akan meningkat dengan dukungan teknologi, baik berupa alat maupun metode penangkapan. Tekanan perubahan iklim membuat beberapa nelayan Indramayu melakukan adaptasi dengan menggunakan teknologi baik dari sisi kapal, alat tangkap dan sistem geoinformasi dan komunikasi.

Dalam upaya peningkatan kapasitas kemampuan produksi ikan tangkap dengan melakukan adaptasi menggunakan 
teknologi tersebut membutuhkan biaya pada besaran tertentu yang sulit dijangkau nelayan Indramayu kebanyakan. Beberapa nelayan pemodal besar mampu menjangkaunya. Namun, nelayan-nelayan dengan modal kecil sulit menjangkaunya terutama dalam hal teknologi kapal dan teknologi alat tangkap. Data makro menunjukkan bahwa nelayan Indramayu kebanyakan nelayan kecil misalnya saja pada tahun 2009 jumlah nelayan motor tempel sebesar $5620(6,77 \%)$ sedangkan kapal motor 408 (93,23\%). Secara mikro, fakta yang ditemukan di lapangan berdasarkan hasil wawancara menunjukkan bahwa masyarakat dengan modal kecil sulit mengakses teknologi berbiaya tinggi seperti kapal motor dengan alat tangkap gillnet beserta perlengkapan alat lainnya seperti Freezer, GPS, fishfinder harganya mencapai 2,5 miliar.

\begin{abstract}
"Kalo gillnet enak, jangkauannya luas, disini barat (cuaca buruk) di luar sana tidak barat (cuaca baik). Tapi modalnya yang mahal. Gillnet yang punya $H$. Mansyur sampai jaring lengkap 2,5 M, itu belum perbekalan 100-150 juta. Yang belum jadi ada dua.Yang sudah berlayar 1 milik H. Jaeni (punya pursein 1 gillnet 1). Pursein 1, tidak sampai 1,5 M. Gillnet 120 pis ( 1 pis $100 \mathrm{~m}$ ) alat tangkap gillnet hampir 1 M. kemudian perlu freezer untuk menyimpan ikan supaya tahan lebih lama" (wawancara nelayan, 2013).
\end{abstract}

Lopez (2011) dalam penelitiannya pada masyarakat pertanian di Kamboja mengungkapkan bahwa kemampuan beradaptasi dengan teknologi sudah dimiliki petani di Kamboja, namun memang perlu tetap adanya peningkatan kapasitas pengetahuan lokal masyarakat dalam adaptasi menggunakan teknologi tersebut. Lopez (2011) kemudian menyarankan perlunya dukungan finansial dan kelembagaan untuk mengimplementasikan aktivitas adaptasi di lapangan. Sharma (2011) dalam penelitiannya juga mengungkapkan bahwa kebutuhan spesifik dalam mendukung adaptasi menggunakan teknologi adalah peningkatan kemampuan kapasitas manusia dan kapasitas kemampuan teknisnya dalam memanfaatkan teknologi utnuk adaptasi perubahan iklim. Sharma (2011) juga menambahkan bahwa upayaupaya tersebut perlu diikuti dengan upaya peningkatan informasi dan peningkatan kesadaran serta finansial. Berdasarkan hasil penelitian terdahulu tersebut maka penting untuk juga memperhatikan aspek finansial dari suatu tindakan adaptasi perubahan iklim untuk kelompok masyarakat tertentu. Untuk kasus masyarakat nelayan di Indramayu, sisi finansial tersebut menjadi permasalahan tersendiri dalam kegiatan adaptasi perubahan iklim. Dari uraian sebelumnya, dapat disimpulkan bahwa kurangnya kepemilikan sumber daya finansial merupakan kendala yang siginifikan untuk meningkatkan pemanfaatan teknologi untuk adaptasi perubahan dan variabilitas iklim.

\section{b. Lemahnya Akses Mendapatkan Sumber Daya Finansial}

Dalam hal finansial, pemerintah sebenarnya telah menyediakan akses untuk mendapatkan bantuan dalam meningkatkan kemampuan pemanfatan teknologi. Pemerintah melaksanakan program bantuan langsung berupa kapal dan perlegkapannya serta menyediakan bantuan modal baik dalam skema pinjaman maupun hibah.

Dalam mendukung adaptasi teknologi, pemerintah memberikan bantuan kapal kepada kelompok nelayan. Namun demikian, kapal bantuan tersebut mengalami persoalan.Sebagai contoh, kapal yang diberikan pemerintah kepada kelompok nelayan koperasi Misaya Mina Eretan Wetan masih belum dimanfaatkan oleh nelayan.Kapal tersebut masih bersandar di pelabuhan Eretan Wetan.Kapal belum digunakan dengan alasan kelompok nelayan belum mampu melengkapi kelengkapan kapal tersebut. Kapal tersebut membutuhkan modifikasi lanjutan sesuai kebutuhan nelayan yang akan menjalankannya. Sedangkan biaya untuk melengkapi kelengkapan kapal 
tersebut cukup besar.Selain itu, kapal belum beroperasi karena kapal tersebut masih konflik.Kapal tersebut menimbulkan konflik berupa kecemburuan antara nelayan karena kapal bantuan hanya satu sedangkan banyak nelayan di Eretan Wetan Indramayu.

Pemerintah hanya memberi kapal tanpa dilengkapi perlengkapan. Kami diminta pemerintah untuk melengkapinya dengan perlengkapan kapal. Namun, kami tidak memiliki dana yang cukup untuk menambahkan perlengkapan kapal sampai kapal tersebut bisa difungsikan. Kapal bantuan tersebut perlu modifikasi lagi. Kapal ini juga belum difungsikan karena nelayan lain iri ingin juga mendapatkan bantuan kapal (Wawancara Manajer Koperasi Misaya Mina, 2013).

Selain program bantuan kapal, pemerintah memberikan akses permodalan kepada nelayan yang membutuhkan peningkatan kapal dan peningkatan perlengkapan kapal seperti alat tangkap, alat komunikasi, dan alat geoinformasi.Untuk mendapat bantuan tersebut, nelayan harus mengajukan proposal dengan terlebih dahulu membentuk kelompok kemudian disampaikan ke penyuluh kemudian ke pemerintah. Kondisi tersebut dianggap nelayan terlalu berbelit-belit sehingga menyulitkan nelayan.Tambahan lagi, proposal yang diajukan melalui penyuluh perikanan dianggap oleh nelayan kadang tidak ada tindak lanjutnya. Dengan kondisi tersebut, nelayan cenderung enggan mengajukan proposal pengajuan modal kepada pemerintah. Alternatif akses modal selain dari pemerintah adalah dari swasta. Namun, modal dari swasta mensyaratkan jaminan yang cukup besar sehingga dianggap sulit dan memberatkan oleh nelayan. Nelayan tidak memiliki cukup jaminan mengingat mata pencahariannya yang penuh dengan ketidakpastian.

Dari urian di atas dapat diinterpretasikan bahwa bantuan modal saja tidak cukup untuk menyelesaikan persoalan lemahnya akses terhadap finansial untuk meningkatkan pemanfaatan teknologi. Bahkan, ada kecenderungan memunculkan masalah baru akibat ketidakmerataan pemberian bantuan modal langsung tersebut. Seperti pada contoh, bantuan kapal Inka Mina 357 pada masyarakat nelayan Eretan Wetan. Kapasitas masyarakat dalam mengakses modal tersebut seperti kolektifitas dan kemampuan teknis penyusunan proposal menjadi penting dalam mengakses modal. UNEP (2011) dalam kajiannya mengungkapkan bahwa dalam proses implementasi teknologi membutuhkan software dan orgware. Software dalam konteks sudi ini berupa kemampuan mengakses modal untuk meningkatkan pemanfaatan teknologi, sedangkan orgware dalam konteks studi ini adalah kelembagaan termasuk kolektifitas dalam masyarakat nelayan. Lebih luas lagi UNEP (2011) mengungkapkan bahwa kapasitas adaptif tergantung pada faktor-faktor yang sangat luas terkait pembangunan, termasuk tingkat pendapatan, pendidikan, kelembagaan, kesehatan, pengetahuan, keterampilan dan pengembangan teknologi. Klein (2011) mengungkapkan bahwa teknologi merupakan hal yang penting dalam mengurangi kerentanan terhadap perubahan iklim, namun keefektifannya tergantung pada konteks ekonomi, kelembagaan, hukum, dan sosial budaya di wilayah tersebut. Klein (2011) lebih lanjut mengungkapkan bahwa adaptasi merupakan proses partisipatif yang tidak hanya melibatkan aspek "hard technology" tetapi juga aspek "soft technology" dan "non technology".

\section{Kesimpulan}

Adanya dampak perubahan iklim dan variabilitas iklim berupa kejadian ekstrim (extreme event) cuaca buruk dan cuaca yang tidak menentu mengganggu usaha nelayan dalam produksi ikan tangkap. Dalam merespon dampak tersebut, nelayan melakukan adaptasi dengan memanfaatkan 
perkembangan teknologi kapal, alat tangkap, dan teknologi geoinformasi dan komunikasi.

Dalam rangka mendorong pemanfaatan teknologi produksi ikan untuk adaptasi perubahan iklim dan variabilitas iklim, pemerintah melakukan intervensi melalui program-program bantuan. Program tersebut antara lain bantuan kapal dan perlengkapan kapal, penyediaan danan untuk pinjaman modal, serta penyediaan informasi daerah penangkapan ikan dan iklim.

Namun demikian, adanya kesenjangan antara apa yang disediakan pemerintah (bantuan kapal, bantuan modal dan IDPI) dengan kondisi lapangan yang dihadapi masyarakat nelayan, bahkan beberapa kasus tertentu menimbulkan masalah baru. Salah satu masalah yang muncul adalah ketidakmerataan bantuan tersebut, sehingga terjadi kecemburuan masyarakat pada pihak tertentu yang mendapatkan bantuan kapal dan perlengkapannya. Kondisi tersebut terjadi karena bantuan kapal tidak menjangkau ke semua masyarakat nelayan. Bantuan yang dimaksudkan sebagai stimulan tidak membangkitkan masyarakat untuk mengembangkannya karena adanya konflik dalam internal masyarakat dan belum adanya penyiapan masyarakat untuk mengembangkan bantuan stimulan tersebut.

Selain itu, masalah lain adalah penyediaan informasi daerah penangkapan ikan dan iklim hanya dapat dimanfaatkan oleh kapal besar yang memiliki jangkauan luas. Sedangkan, nelayan perahu kecil tidak dapat memanfaatkannya. Pemerintah sebenarnya mendorong peningkatan kapasitas kapal dengan adanya penyediaan bantuan modal untuk dapat diakses masyarakat. Namun, penyediaan bantuan modal tersebut masih sulit diakses masyarakat nelayan karena dianggap prosedurnya rumit, kurangnya kepercayaan pada pemerintah, dan mensyaratkan kolektifitas masuarakat untuk mengakses bantuan modal tersebut.

Deangan demikian, program penyediaan modal saja tidak cukup mendorong peningkatan pemanfaatan teknologi untuk adaptasi dampak perubahan iklim dan variabilitas iklim. Namun, yang penting adalah upaya-upaya menguatkan kapasitas masyarakat dalam mengakses modal tersebut.

Rekomendasi yang diberikan dalam konteks penguatan kapasitas masyarakat dalam mengakses untuk adaptasi perubahan iklim dan variabilitas iklim bagi masyarakat nelayan Indramayu adalah :

a. Penguatan kolektifitas melalui koperasi antar nelayan

b. Penguatan kerjasama nelayan dan penyuluh

c. Pendampingan melalui agen eksternal dan agen internal dalam hal pengajuan proposal bantuan modal dan pemanfaatan modal

Dalam artikel ini juga merekomendasikan perlunya studi lanjutan. Studi lanjutan tersebut antara lain mengenai bagaimana transfer teknologi yang efektif, identifikasi alternatif sumbersumber/mekanisme pembiayaan pengembangan pemanfaatan teknologi di masyarakat nelayan. Selain itu, terdapat indikasi adanya tekanan dari dimensi manusia, ekonomi dan lingkungan yang menekan nelayan selain dari perubahan iklim dan variabilitas iklim, studi lanjutan perlu memasukkan dimensi tersebut.

\section{Acknowledgement}

Tulisan ini merupakan bagian dari penelitian dengan judul "Adaptasi Berbasis Teknologi sebagai Respons terhadap 
Perubahan Iklim : Studi Kasus Indramayu

“ yang dibiayai oleh LPPM-Institut Teknologi Bandung. Kami berterima kasih kepada rekan-rekan di Laboratorium Perencanaan Wilayah Sekolah Arsitektur, Perencanaan dan Pengembangan Kebijakan atas bantuannya dalam pengumpulan data dan diskusi.

\section{Referensi}

- Adger, W.N., Kelly, P.M., Winkels, A., Huy, L.Q. and Locke, C., 2002. Migration, remittances, livelihood trajectories, and social resilience. AMBIO: A Journal of the Human Environment, 31(4): 358-366.

- Ankiewicz, P., De Swardt, E. and De Vries, M., 2006. Some implications of the philosophy of technology for science, technology and society (STS) studies. International Journal of Technology and Design Education, 16(2): 117-141.

- Australian Government, 2009. Vulnerability To Climate Change Impacts And Adaptation Response Options. Australian Government Departemen of Climate Change.

- Budiono, M., 2001. Peran Ilmu dan Teknologi Dalam Peradaban Manusia. In: B. Kombaitan (Editor), Dasar-Dasar Teknologi dan Kerekayasaan Bidang Keilmuan Teknik Sipil, Lingkungan Binaan, dan Perencanaan Fakultas Teknik Sipil dan Perencanaan ITB.

- Badjeck, M., Allison, E., Halls, E. 2010. Impacts of climate variability and change on fishery-based livelihoods. Marine Policy 34 (2010) 375-383

- Klein, R.J., Nicholls, R.J., Ragoonaden, S., Capobianco, M., Aston, J. and Buckley, E.N., 2001. Technological options for adaptation to climate change in coastal zones. Journal of Coastal Research: 531-543.

- Mitcham, C., 1994. Thinking through technology: The path between engineering and philosophy. University of Chicago Press.

- Nagy, G.J., Bidegain, M., Caffera, R., Lagomarsino, J., Norbis, W., Ponce, A. and Sención, G., 2006. Adaptive capacity for responding to climate variability and change in estuarine fisheries of the Rio de la Plata. AIACC Working Series Paper No, 36.

- Pauly, D.,Watson, R., Alder, J. 2005. Global trends in world fisheries: impacts on marine ecosystems and food security. Phil. Trans. R. Soc. B 2005 360, doi: 10.1098/rstb.2004.1574, published 29 January 2005

- Sagala, S., Pratama, A.A., Argo, T.A. and Asirin., 2012. Remitan TKI dan Faktor-faktor yang mempengaruhinya dalam Pengurangan Risiko Bencana Kenaikan Permukaan Air Laut, Studi Kasus di Wilayah Perkotaan Indramayu Jurnal Perencanaan Wilayah dan Kota "Tata Loka", ISSN 0852-7458.

- Sani, I.R, Sagala, S. Fishermen Adaptation to cope with environtmental risks in Indramayu District. Planocosmo International Seminar

- Santikarn, M., 1981. Technology Transfer. Singapore University Press.

- Smit, B., Burton, I., Klein, R.J. and Street, R., 1999. The science of adaptation: a framework for assessment. Mitigation and adaptation strategies for global change, 4(3-4): 199-213.

- UNDP, 2007. The Other Half of Climate Change. UNDP Indonesia. 